\title{
Creativity in Higher Education According to Graduate Programs' Professors
}

\author{
Eunice Maria Lima Soriano de Alencar ${ }^{1}$, Zélia Maria Freire de Oliveira ${ }^{2, *}$ \\ ${ }^{1}$ Instituto de Psicologia, Universidade de Brasilia, Brazil \\ ${ }^{2}$ Universidade Católica de Brasília, Brazil
}

Copyright $(2016$ by authors, all rights reserved. Authors agree that this article remains permanently open access under the terms of the Creative Commons Attribution License 4.0 International License

\begin{abstract}
There is an increasing awareness of the importance of fostering creativity in higher education. The benefits of creativity to individuals and societies have also been increasingly recognized, as well as the key role of higher education in the information age. In spite of this recognition, there has been little research exploring creativity in graduate courses. This study addresses this issue. We examined professors' view of the importance attributed to creativity in higher education, especially in graduate programs, and what actions the University, as an institution responsible for the development of professionals, should take to stimulate professors' and students' creativity. Twenty Brazilian professors were interviewed and the data were submitted to content analysis. The results indicated that all professors considered creativity very important in higher education, especially in Sciences and Humanities graduate programs. The reasons for why it is important to foster creativity in higher education were related to its role in the production of knowledge, innovation, society's demands, and the possibility of using creative strategies to motivate students. The participants suggested planning and promotion of several activities that encourage creativity, the removal of barriers that stunt creativity and infrastructure improvement as procedures to enhance professors' and students' creativity by the higher education institution.
\end{abstract}

Keywords Creativity, Higher Education, Professor, Graduate Programs, University

\section{Introduction}

An increasing rate of changes, uncertainties, challenges and problems characterizes today's world. It is an epoch of complexity, disorder, ambiguity. The internet and the new media have shortened time and distance. The labor market is increasingly competitive, demanding employees who can successfully meet the workplace challenges, innovate, act quickly and present effective solutions to unexpected problems [1-7]. In this scenario, creativity is of utmost importance, a survival skill that needs to be nurtured in different contexts.

Scholars from various fields highlight the need of a great attention to the development of the creative capacity across the various levels of education, especially in higher education. The benefits of creativity to individuals and societies, as well as the key role of higher education for the development of a knowledge society have been recognized $[8,9]$. Governments of several countries, such as China and England, have taken initiatives aiming at the implementation of educational policies that ensure the development of creativity through education,

Paradoxically, despite the recognition of the importance of developing students' creative abilities, not only in early education but also in higher education, as a condition to prepare students to succeed in an uncertain future, there is agreement that creativity has not received the necessary attention in university courses [10-16]. On the contrary, scholars have pointed out several inhibiting factors to the nurturance of creativity in higher education. Jackson (14) remembers, for example, that many professors of higher education have limited knowledge about the diversity of strategies that could be used to stimulate creativity in teaching their disciplines and also that many of them appreciate creativity only on a rhetorical level. Fryer [17], in a study with 90 teaching fellows who were interviewed about different aspects related to creativity and its promotion in higher education, identified several conditions that limit the opportunities for developing students' creativity, such as inadequate preparation time, excessive non-teaching workload and insufficient class contact time.

Factors that restrict the promotion of students' creative potential in higher education classes were also noticed in several studies conducted in Brazil [18-20]. Alencar and Fleith [18], in a study with 338 undergraduate professors who completed a checklist of barriers to the promotion of conditions conducive to creativity in higher education courses, observed that barriers related to the students were pointed out by a great number of professors, such as students 
with learning difficulties, students' lack of interest in the content taught, and a great number of students in the classroom. Findings also revealed that other frequent inhibitors were few opportunities to discuss and exchange ideas with colleagues on instructional strategies and a high number of courses and other activities under the professor's responsibility, which limit preparation time for the teaching practice. Factors that hinder the promotion of students' creative expression were also examined in a study with 20 professors of language courses who were interviewed about creativity in their previous training and pedagogical practices [19]. The sample reported several inhibiting factors to students' creative development, including students' characteristics, such as shyness, fatigue, lack of motivation, resistance to change and to the new, besides lack of prerequisites for higher education studies. The participants also mentioned elements of the higher education institutions where they work, taken by them as hindrances to the promotion of creativity, such as lack of resources and resistance to new pedagogical practices by their colleagues. Similarly, Lima and Alencar [20] found, in a study with 15 professors from graduate programs in education, that elements related to the students (such as a gap in the previously training and fear of expressing ideas), to the professors (such as lack of time and flaws in previous training), and others related to the higher education institution and agencies that regulate graduate courses, were inhibiting factors to the fostering of creativity in the higher education setting.

Studies conducted with students also revealed low incentive to creativity in higher education contexts. Alencar [21] noted, for example, in a study with 428 undergraduates, that, according to the participants, there is not much incentive to the development and expression of students' creativity. Furthermore, students evaluated themselves and their colleagues as significantly more creative than their professors. Also data obtained by Hosseini [13] in a sample of 450 university students in Iran revealed the predominance of professors' tendency to rely on didactic, memory-based instruction, using pedagogical procedures that reduce students' creativity and motivation. Similarly, Oliveira [22] observed that, according to several of the 20 graduate students who were interviewed about creativity in higher education, there were deleterious practices to the development of students' creativity in the disciplines attended by them, such as requirements of routine work, professor's criticisms to new perspectives taken by students, restriction to autonomy, and rigidity of the disciplines program.

Despite the increasing number of research on creativity in higher education, the review of literature indicated scarcity of studies conducted with professors of graduate programs. These programs have as one of their main purposes the preparation of new researchers, from whom it is expected the contribution to the advancement of knowledge, as well as to the solution of problems faced by society nowadays. So, in our view, it is of foremost importance that creativity be injected in these programs. This study addresses this issue. Professors' view of the importance attributed to creativity in higher education, especially in graduate programs, and the actions the University, as an institution responsible for the formation of professionals, should do to stimulate professors' and students' creativity were examined.

\section{Materials and Methods}

\subsection{Sample}

The participants were 20 professors of graduate programs in several fields (Communication, Information Science, Administration, Education, Anthropology, Psychology, Geoscience, Mathematics, Transports/Engineering, Animal Sciences, Molecular Biology, and Molecular Pathology). All of them worked in one of the best Brazilian universities.

Twelve were male and 8 were female. The participants' age ranged from 33 to 65 years ( $M=49.3$ years). They had two to 28 years of experience in teaching higher education disciplines $(M=16.2$ years). Their degree of satisfaction in teaching at the university, in a scale from 1 to 10 , ranged from 5 to $10(\mathrm{M}=8.17)$.

Fifteen professors declined to participate in the study. Eleven did not answer the request sent by emails and four refused to participate, with the justification of lack of time, excess of work or indifference to the subject dealt with in the interview.

\subsection{Procedure and Analysis}

Semi-structured interviews were carried out within the participants' office. The interviews lasted from 20 to 70 minutes ( $M=42$ minutes). It was difficult to schedule a time to interview several professors due to their many duties. Four of them informed that they did not have time to be interviewed for more than 30 minutes. After collecting some biographical data and the degree of satisfaction in teaching university courses, open questions were asked about conception and importance of creativity in society; characteristics of creative students; pedagogical strategies used by the professors to foster students' creativity; models of creative people met along their lives; the importance of fostering creativity in higher education, especially in graduate programs; and actions universities should take to stimulate professors' and students' creativity. The results obtained in relation to the first four topics were published previously [23].

The interview protocol was used as a guide, but the course of the interview dialogue was determined by the professors' responses. All the themes of interest were covered by most respondents, but not necessarily in the order listed in the protocol. The interview tapes were transcribed verbatim and the data were subjected to content analysis, according to Bardin [23] and Gibbs [24]. 
The participation in the study was voluntary. The confidentiality of the responses was assured to the participants, thus fulfilling the legal ethical requirements.

\section{Results}

\subsection{The Importance of Creativity in Higher Education}

According to all participants, creativity is very relevant in higher education, especially in graduate programs. All of them pointed out that higher education must be concerned with the development of students' creativity. Two professors even highlighted that education for creativity should start in elementary school, as illustrated in the following response:

I think that if we could take the fostering of creativity to the first years of school, the gains would be much higher.

A professor called attention to the fact that higher education is very conservative:

Of course I agree. However, I think that there are still some areas of science that are too rigid, are cast in old patterns. [The professors] do not accept ... the staff is very conservative.

Another professor pointed out the distance that exists between university and industry, due to the low incentive to creativity:

I believe so [it is important]. But I still see a very large distance between University and industry that possibly is the element that will provide propulsion for creative development in the area of exact sciences, which is my area.

The reasons given by professors to the importance of fostering creativity were distributed in the following categories:

(a) Graduate studies/research, covering topics like being the 'soul' of research; breaking boundaries; helping in the organization and classification of thoughts; and being the foundation for the production of knowledge:

In respect to higher education, in respect to graduate programs, this is much more important, because the University, as a center of knowledge production, so to speak, as a safeguard of knowledge, isn't it? The university, in general, is charged to advance, to test, with the most various methods, new solutions to the problems, to the challenges of humanity, of society, ultimately of all situations. So, to stimulate, to encourage and to investigate creativity at the University, at graduate school, is extremely important. It is in the university where there are, at least in principle, the individuals better prepared to have new ideas, to have new and creative ideas for new problems that emerge, all the time, in the world.
So I see it as a paradox, that there are many things and many activities inclined to standardization and, obviously, standardization is a simplification. On the other hand, we have a creativity that seeks to fill gaps and find new paths.

Taken into account that we are preparing researchers and that the problem is the motor of the research, it is extremely important that students learn to elaborate a new problem.

Creativity related to research, we could say that it is the soul, that is, the natural movement of the research, when working with cutting-edge research, when working with cutting edge technology... And the main goal of a graduate program, master's and $\mathrm{PhD}$ program is breaking boundaries.

(b) Innovation, comprising essential reasons for innovation and new solutions:

So, creativity, in general, in human activities, is ... It is important because it generates innovation, new solutions to escape from standardized activities. That is, when there are some standardized activities or standard situations, they tend to have their problems and also require new solutions. It is exactly creativity that leads you to find new solutions, to find new paths.

(c) Society's demands

I have to be creative because the world demands that I be creative.

(d) Motivation, helping to spark students' interest in classes:

When you are working as a teacher, independently of being in graduate or undergraduate courses, the purpose is that you teach, encourage, and try to awake students' interest on a subject or a topic. So, creativity would be fundamental, because, in general, when you use some creative strategies or, simply, when you are able to contextualize something that is part of the content of your disciplinary field, and the student realizes what he/she is listening to, I mean, what is being presented in the content, it is not something so far from and, on the contrary, is close to student's reality, I think it greatly facilitates learning, and brings the student very close to the teacher and to the actual content of the discipline.

When justifying the importance of creativity, three professors also stressed that creativity has not been stimulated as it should be, because of norms and practices that stunt it:

Now, unfortunately, in our country, in general, creativity is ignored. So, we can observe the low level of patent registration in Brazil and this is the direct result of the lack of a system of innovation, 
which involves creativity and, above all, motivation for people.

I have a point of view that the idea of graduate education in Brazil is still very archaic. We also could demand a little more from graduate students. I see that they are more or less molded in the traditional pattern of undergraduate education, which results in certain accommodation on the part of them.

\subsection{Actions to Be Taken by the University to Enhance Professors' and Students' Creativity}

The professors' responses to the question about what the University, as an institution responsible for the formation of professionals, could do to stimulate professors' and students' creativity, were distributed in the following categories:

(a) Planning and fomentation of different activities that encourage creativity, as, for example, creation of a meeting center, forums for debates, professional development programs for professors, with the theme of creativity:

Meeting center. I miss a space to talk, not only about work; ... a meeting place; a meeting with faculty and students together.

(b) Removing barriers that stunt creativity (rules, patterns, bureaucracy, conservatism, requirement of great amount of publications, a single system of evaluation, the undervalue of professor's creative effort:

The bureaucratic aspect of the university is extremely rigid.

... the thought patrol of everybody who does not fit in the current form.

I think there are still some areas of science that are too rigid, are stuck in old patterns... The staff is very conservative, does not support innovation.

What I see is a great number of papers presented in conferences which are merely repetition. People are still talking about the same thing, repeating, repeating ... I think that this kills creativity terribly... a thing of mechanical, industrial scale.

I think that what the University can do is to be more open, allowing the professor to have more freedom to assess his/her students ... not a single evaluation method, not the same evaluation for everyone, because they are different people.

(c) Infrastructure improvement, enabling professors to have sufficient and up-to-date technologies, adequate rooms, material resources, laboratories:

As an institution, it could offer better resources in order for it to be possible to teach more creative classes, with the use of more technology.

Several professors pointed out that to be interviewed about possibilities of the university in terms of creativity led them to reflect about creativity in school and in the social context, as illustrated in the following responses:

Maybe, we have to rethink and to start investing in creativity since elementary school, for people to be creative. But, on the other hand, is our society ready for creative people? Is the legislation, the State prepared to deal with creative people? The University... The university, suffering all these years with all its administrative processes, still continues, anywhere in the world where I have gone, a barn of scientific and technological development.

We, in Brazil, we don't have the practice of awakening student's curiosity, since the beginning of elementary school, and I think that curiosity and creativity are things that go together. If we have an environment in which a child of 6,7 years, 10 years ... live together in an environment of curiosity, research, laboratory in schools, certainly we would have more creative children, much better prepared at this early stage that would reverberate in high school and, certainly, we would meet here at the University young people much more concerned with producing knowledge than simply acquiring knowledge.

\section{Discussion}

The results revealed that the participants were aware of the importance of enhancing students' creativity in higher education. This is in agreement with Jackson [15], who stated that many professors recognize the value of promoting creativity in their students, and with previous studies [17, 19] with samples of teaching fellows. Yet, Jackson and Shaw [25] observed that although academics, as individuals, believe that creativity is important, they do not value it in their disciplines beyond the rhetorical level. Also Cropley [26] stated that in theory teachers overwhelmingly agree that creativity should be fostered in the classroom, but this is not a reality in their classrooms.

The participants reported several reasons for the importance of fostering creativity in higher education, in special in graduate programs. Its contribution to the production of knowledge and innovation; the demands of creativity by society, which may be considered even as a survival skill in $21^{\text {st }}$ century; the beneficial effects of pedagogical procedures that emphasize creativity on students' motivation were some of the reasons given by professors to justify their responses on the importance of fostering creativity in the educational setting. These factors have been discussed extensively in the literature on creativity. Jackson [14], as well as Alencar and Fleith [18], Romo [27], and Jackson, Oliver, Shaw, and Wisdom [8] call attention to the essential role of creativity in the knowledge society. Creativity as an essential ingredient to innovation is addressed by several scholars, such as Alencar [28] and Bruno-Faria, Vargas and Martínez, [29]. These authors 
remind that creativity is a critical element for the survival of many companies, in view of the challenges generated by globalization and accelerated rhythm of change that have driven organizations to remain in a continuous process of innovation, which requires better uses of the creativity of their human resources. The impact of creative teaching practices on students' motivation is also highlighted by Cropley [26] and Wechsler and Souza [30].

Suggestions given by the participants to enhance professors' and students' creativity included the removal of barriers that have been pointed out in previous studies [17, $20,31]$, such as lack of resources, assessment processes, and bureaucracy. To overcome some of the barriers identified by scholars requires changes in the university organizational system and culture. It requires the inclusion of new policies and management practices that value creativity and facilitate its flourishment in university, offering students more opportunities to express and develop their creative potential, with less pressure of formal modes of learning and assessment.

It is our view that professors need to be aware of their own creative abilities that some of them even ignore. Professors also need to be familiarized with the literature on creativity in higher education, with access to information about pedagogical strategies that can be used in the classroom for the development of creativity and about the various factors associated with creative expression. Also important is to encourage the development of professors' creativity during their period of formation, that is, in institutions that prepare future professors. This should not be done not only through a specific discipline, but through a system of truly creative teaching and learning, in which the future professors experience as students, what they can do later in the classroom, as suggested by Martínez [32].

\section{Conclusions}

The development of creativity cannot be restricted to higher education. Its development should be encouraged from an early age. This would allow students to start higher education better equipped to pursue novel ideas, as well as to be more receptive to challenges. Furthermore, the university is the final step for vocational training. For this reason, it should foster students' creativity, preparing them for the world of work, which requires several characteristics associated with creativity, such as risk taking, flexibility, autonomy and original thought. More specifically in respect to graduate programs, it is important to highlight one of their main goals: the preparation of researchers to contribute to the advancement of the knowledge needed by society in different fields. This requires creativity. However, for the flourishing of creativity in higher education, it is necessary an environment conducive to it that includes resources, the recognition of its importance in teaching and learning, a climate that encourages/favors its expression, as well as professors motivated to design courses with the presence of creativity

To finalize, it is important to highlight that the development and expression of creativity suffer the influence of numerous factors that go beyond the classroom and the educational institution. Its development is complex and involves elements embedded in various contexts. Some of them are nearer the students, such as family values and practices, and classmates' characteristics. Other factors, more remote, are of historical-cultural order, and include, for example, opportunities provided by society for the development and expression of creative talent in different areas, as well as modalities of creative expression recognized and valued. It is important not to lose sight of the diversity of factors that contribute to the flowering of creativity. This helps to understand better the phenomenon, its multiple facets and determinants.

\section{REFERENCES}

[1] G. R. Oldham, M. Baer. Creativity and the work context. In M. Mumford (Ed.). Handbook of organizational creativity, Academic Press, London, 387-420, 2012.

[2] M. Casttels. A era da informação: economia, sociedade e culturas. A sociedade em rede [The era of information: Economics, society and cultures. Society interconnected], vol. 1, 7th ed., Paz e Terra, Rio de Janeiro, 2003.

[3] M. Casttels. A era da informação: economia, sociedade e culturas. Fim de milênio [The era of information: Economics, society and cultures. End of a millenium], vol. 3, 7th ed., Paz e Terra, Rio de Janeiro, 2003.

[4] A. Giddens. Sociologia [Sociology]. Fundação Calouste Gulbenkian, Lisboa, 2008.

[5] E. Morin. Educação e complexidade: os setes saberes e outros ensaios [Education and complexity: The seven knowledges and other essaays],Cortez, São Paulo, 2002.

[6] E. Morin. Introdução ao pensamento complexo [Introduction to complex thought], Sulina, Porto Alegre, 2007.

[7] F. Ponti, X. Ferrás. Pasión por inovar [Passion for innovate], Granica, Barcelona, 2006.

[8] N. Jackson, M. Oliver, M. Shaw, J. Wisdom. Developing creativity in higher education, Routledge, London, 2007.

[9] S. M. Wechsler, T. C. Nakano. Criatividade no ensino superior: uma perspectiva internacional [Creativity in higher education: An international perspective], Vetor, São Paulo, 2011.

[10] E. M. L. S. Alencar, D. S. Fleith. Criatividade. Múltiplas perspectivas [Creativity. Multiple perspectives], Editora da UnB, Brasília, 2009

[11] M. Csikszentmihalyi. Developing creativity. In N. Jackson, M. Oliver, M. Shaw, J. Wisdom (Eds.). Developing creativity in higher education, Routledge, London, pp. xviii-xx, 2007. 
[12] A. P. David, T. C., Nakano, M. F. Morais, R. Primi. Competências criativas no ensino superior [Creative competencies in higher education]. In S. M. Wechsler, T. C. Nakano. Criatividade no ensino superior: uma perspectiva internacional [Creativity in higher education: An international perspective], Vetor, São Paulo, 14-53, 2011.

[13] A. Hosseini. University student's evaluation of creative education in universities and their impact on their learning, Procedia Social and Behavioral Sciences, Vol. 15, 1806-1812, 2011.

[14] N. Jackson. Creativity in higher education. Creating tipping points for cultural change. SCEPTrE Scholarly Paper, Guildford. Vol. 3, 1-25, 2006.

[15] N. Jackson. Imagining a different world. In N. Jackson, M. Oliver, M. Shaw, J. Wisdom (Eds.). Developing creativity in higher education, Routledge, London, 1-19, 2007.

[16] S. M. Wechsler. Criatividade e desempenho escolar: uma síntese necessária [Creativity and school achievement: A necessary synthesis]. Linhas Críticas, Vol. 8, No. 15, 179-188, 2002.

[17] M. Fryer. Facilitating creativity in higher education: A brief account of National Teaching Fellows' views. In N. Jackson, M. Oliver, M. Shaw, J. Wisdom (Eds.). Developing creativity in higher education, Routledge, London, 74-88, 2007.

[18] E. M. L. S. Alencar, D. S. Fleith. Criatividade na educação superior: fatores inibidores [Creativity in higher education: Inhibiting factors], Avaliação Psicológica, Vol. 15, No. 2, 201-206, 2010.

[19] Z. M. F. Oliveira, E. M. L. S. Alencar. S. Criatividade na formação e atuação do professor do curso de Letras [Creativity in the linguages course and the professor's formation and performance]. Psicologia Escolar e Educacional, Vol. 11, No. 2, 223-237, 2007.

[20] V. B. F. Lima, E. M. L. S.Alencar. Criatividade em programas de pós-graduação em educação: práticas pedagógicas e fatores inibidores [Creativity in graduate programs in education: Pedagogical practices and inhibiting factors]. Revista Psico USF, Vol. 19, No.1, 61-72, 2014.
[21] E. M. L. S. Alencar. O estímulo à criatividade no contexto universitário [The incentive to creativity in the university context]. Psicologia Escolar e Educacional, Vol. 1, no.2-3, 29-32, 1997.

[22] Z. M. F. Oliveira, E. M. L. S. Alencar. Criatividade na pós-graduação stricto sensu: uma presença possível e necessária [Creativity in graduate courses: a possible and necessary presence]. Revista de Educação Pública, Vol. 23, n. 52, 53-75, 2014.

[23] L.Bardin. Análise de conteúdo [Content analysis], 3. ed., Edições 70, Lisbon, 2004.

[24] G. Gibbs. Análise de dados qualitativos [Qualitative data analysis], Artmed, Porto Alegre, 2009.

[25] N. Jackson, M Shaw. Developing subject perspectives on creativity in higher education. In N. Jackson, M. Oliver, M. Shaw, J. Wisdom (Eds.). Developing creativity in higher education, Routledge, London, 89-108, 2007.

[26] A. J. Cropley. Creativity in education \& learning, Routledge, London, 2005.

[27] M. Romo. Psicología de la creatividad [Psychology of creativity], Paidós, Barcelona, 2012

[28] E. M. L. S. Creativity in organizations: Facilitators and inhibitors. In M. Mumford (Ed.). Handbook of organizational creativity, Academic Press, London, 87-114, 2012.

[29] M. F. Bruno-Faria, E. R. Vargas, A. M. Mitjáns. Criatividade e inovação nas organizações [Creativity and innovation in organizations], Atlas, São Paulo, 2013.

[30] S. M. Wechsler, V. L. T. Souza Criatividade e aprendizagem [Creativity and learning], Loyola, São Paulo, 2011.

[31] M. Edwards, C. McGoldrick, M. Oliver, M. Creativity and curricula in higher education: Academics perspectives. In N. Jackson, M. Oliver, M. Shaw, J. Wisdom (Eds.). Developing creativity in higher education, Routledge, London, 59-73, 2006.

[32] Martínez, A. M. A criatividade na escola: três direções de trabalho [Creativity in school: Three work directions]. Linhas Críticas, Vol. 8, No. 15, 189-206, 2002. 